\title{
Early changes in enzyme activity during the development of and recovery from vitamin $D$ deficiency in the rat
}

\author{
By ELISABETH M. CHEESMAN, ALICE M. COPPING \\ AND PATRICIA M. PREBBLE \\ Departments of Nutrition and Physiology, Queen Elizabeth College, \\ University of London, Campden Hill Road, London, $W 8$
}

(Received 9 August 1965-Accepted 17 February 1966)

\begin{abstract}
I. Rats were given a rachitogenic diet with or without vitamin $D$ for $1,2,3$ or 4 weeks, and vitamin $D$ was administered to a group of rats which had been deprived of vitamin $D$ for 3 weeks. 2. Changes in enzyme activities of some tissues were followed histochemically. In general, changes in parathyroid preceded those in gut and kidney. Leucine aminopeptidase activity rose in the parathyroid, kidney and jejunum of the vitamin D-deficient rat as did the ribonucleic acid content of the parathyroid and the dehydrogenase activity of the gut. In contrast, the phosphatase activity of the gut and kidney fell in the vitamin D-deficient rat. All these changes were reversed during the 1 -week recovery period. 3 . A slower response of bones to both vitamin $\mathrm{D}$ deprivation and vitamin $\mathrm{D}$ dosage after deprivation was indicated by the changes in the percentages of ash in the bones and the changes in number and distribution of osteoclasts.
\end{abstract}

In a previous study (Cheesman, Copping \& Prebble, I964) a comparison was made of enzyme activities in the tissues of normal and vitamin D-deficient rats after 4,5 and 7 weeks of deprivation. Among the differences observed was a consistent rise in leucine aminopeptidase activity in the parathyroids of the deficient rat. Since the parathyroid is so intimately concerned with the distribution of calcium and phosphorus, changes in other tissues could be secondary to those of the parathyroid rather than primary effects of the lack of vitamin D.

In the present study some rats were deprived of vitamin $\mathrm{D}$ for shorter periods and some deficient rats given a curative dose of vitamin $\mathrm{D}$, to determine whether enzyme activities of other tissues altered before those of the parathyroid during either depletion or recovery.

\section{EXPERIMENT AL}

\section{Animals and procedure}

Pairs or trios of male rats, of the Lister Institute black and white stock maintained at Queen Elizabeth College, were placed on a rachitogenic diet with or without vitamin D (Cheesman et al. I964) at 28 days of age and maintained on the diet for $\mathrm{I}$, 2 or 3 weeks in experimental series $C_{35}$ and for 4 weeks in series $C_{38}$. In series $C_{35}$ one animal of each pair received vitamin $\mathrm{D}$ for the whole experimental period and the other received none. In series $\mathrm{C}_{3} 8$ one animal of each trio received vitamin $\mathrm{D}$ for the whole experimental period, one animal received vitamin $\mathrm{D}$ for the last week of the period only and the third received none.

In series $C_{35}$ one normal and one deficient animal were killed on each occasion 
and in series $\mathrm{C}_{38} 8$ a trio of one normal, one recovery and one deficient animal was killed. The pairs or trios of animals were always litter-mates and were not identified as normal, recovery or deficient until all the comparisons had been completed.

\section{Preparation of tissues}

The animals were killed and the tissues prepared for histochemical methods as described previously (Cheesman et al. 1964).

The right femur, tibia and fibula were stored at $-27^{\circ}$. When each series was completed the percentage of ash in the dry fat-free bones was measured by the method of Hume, Pickersgill \& Gaffikin (1932). In series $\mathrm{C}_{3} 8$ the left radius and ulna were decalcified in cold EDTA (Balogh, 1962) and sections cut at $15 \mu \mathrm{m}$ in a cryostat.

\section{Histochemical methods}

Alkaline phosphatase, acid phosphatase, glucose-6-phosphatase, lactate dehydrogenase and leucine aminopeptidase were localized as described previously (Cheesman et al. 1964).

Succinate dehydrogenase was demonstrated by the method of Nachlas, Tsou, de Souza, Cheng \& Seligman (Pearse, I960, p. 910). Duodenum and jejunum were incubated for $20 \mathrm{~min}$ at $37^{\circ}$ and radius and ulna for $30 \mathrm{~min}$ at $37^{\circ}$.

Ribonucleic acid was demonstrated on cryostat sections of parathyroid by the method of Brachet (Pearse, 1960, p. 825) after fixation in $4 \%(\mathrm{v} / \mathrm{v})$ formaldehyde. The staining time was $x_{5}$ min.

\section{Histochemical scoring}

Pairs of sections were examined with a Britex projection comparator (Pyser-Britex Ltd, 329 High Holborn, London, WC 1 ).

Scoring was essentially as in Cheesman et al. (1964) but the scale was extended so that differences in activity were scored from $\circ$ (no difference in activity) to \pm 4 (a very great difference in activity). When the section from the normal animal had the greater activity the score was + . When the section from the deficient animal had the greater activity the score was - . When normal and recovery animals were compared greater activity in the recovery animal was scored - . When deficient and recovery animals were compared greater activity in the recovery animal was scored + .

\section{RESULTS}

\section{Weight increases}

There were no significant differences between the weekly weight gains of the normal and deficient animals after $\mathrm{I}, 2$ or 3 weeks of vitamin D deprivation (Table $\mathrm{I}$ ). However, after 4 weeks the normal animals had gained significantly more weight than both the deficient animals $(P<0.05)$ and the recovery animals $(P<0.01)$. Comparison of the weight gains during the $4^{\text {th }}$ week showed that the weight gain of the recovery animals tended to be smaller than the weight gain of the deficient animals although the recovery group had now received vitamin $D$. 


\section{Parathyroid}

The means of the histochemical scores for the parathyroid are given in Table 2.

No rise in leucine aminopeptidase activity in the deficient rats was observed at the end of the Ist week but a rise was seen in animals maintained on the diet for 2 $(P<0.05), 3(P<0.01)$ and $4(P<0.01)$ weeks. When vitamin $\mathrm{D}$ was given for I week after 3 weeks' depletion the parathyroids of these recovery animals were not different from the normal; their leucine aminopeptidase activity was significantly less than that of the deficient group $(P<0.01)$.

Table 1. Mean values with their within-litters standard errors for weight gain of rats given a rachitogenic diet with or without vitamin $D$ in series $C_{35}$ and $C_{3} 8$

\begin{tabular}{|c|c|c|c|c|}
\hline Series no. & $\begin{array}{l}\text { Dosing } \\
\text { period } \\
\text { (weeks) }\end{array}$ & $\begin{array}{c}\text { Weekly } \\
\text { dose of } \\
\text { vitamin } D \\
\text { (i.u.) }\end{array}$ & $\begin{array}{l}\text { No. of } \\
\text { rats }\end{array}$ & $\begin{array}{l}\text { Weekly weight } \\
\text { gain (g) }\end{array}$ \\
\hline $\mathrm{C}_{35}$ & $\begin{array}{l}\text { I } \\
\text { I }\end{array}$ & $\begin{array}{l}0 \\
10\end{array}$ & $\begin{array}{l}\text { 10 } \\
\text { 10 }\end{array}$ & $\left.\begin{array}{l}4.8 \\
3 \cdot 1\end{array}\right\} \pm 0.56$ \\
\hline $\mathrm{C}_{35}$ & $\begin{array}{l}2 \\
2\end{array}$ & $\begin{array}{l}0 \\
10\end{array}$ & $\begin{array}{l}8 \\
8\end{array}$ & $\left.\begin{array}{l}5.8 \\
5.8\end{array}\right\} \pm 0.43$ \\
\hline $\mathrm{C}_{35}$ & $\begin{array}{l}3 \\
3\end{array}$ & $\begin{array}{l}0 \\
\text { 10 }\end{array}$ & $\begin{array}{l}8 \\
8\end{array}$ & $\left.\begin{array}{l}8 \cdot 2 \\
7 \cdot 9\end{array}\right\} \pm 0.43$ \\
\hline $\mathrm{C}_{38} 8$ & $\begin{array}{l}4 \\
4\left\{\begin{array}{l}\text { for } \\
\text { for }\end{array}\right.\end{array}$ & 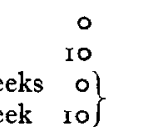 & $\begin{array}{l}\text { 10 } \\
\text { 10 } \\
\text { 10 }\end{array}$ & $\left.\begin{array}{l}8 \cdot 1 \\
9 \cdot 1 \\
7 \cdot 7\end{array}\right\} \pm 0.30$ \\
\hline
\end{tabular}

Table 2. Mean values with their standard errors for the differences in histochemical scores of the parathyroids of rats given a rachitogenic diet with or without vitamin $D$

\begin{tabular}{|c|c|c|c|c|c|c|}
\hline $\begin{array}{c}\text { Series } \\
\text { no. }\end{array}$ & $\begin{array}{l}\text { Dosing } \\
\text { period } \\
\text { (weeks) }\end{array}$ & $\begin{array}{l}\text { No. of } \\
\text { pairs } \\
\text { of rats }\end{array}$ & Comparison & $\begin{array}{l}\text { Lactate } \\
\text { dehydro- } \\
\text { genase }\end{array}$ & $\begin{array}{l}\text { Leucine } \\
\text { amino- } \\
\text { peptidase }\end{array}$ & $\begin{array}{c}\text { Ribonucleic } \\
\text { acid }\end{array}$ \\
\hline$C_{35}$ & I & IO & $N$ v. $D$ & $-0.4 \pm 0.22$ & $+0.1 \pm 0.31$ & - \\
\hline$C_{35}$ & 2 & 8 & $N v . D$ & $-0.1 \pm 0.23$ & $-\mathbf{I} 5 \pm 0.47$ & — \\
\hline $\mathrm{C}_{35}$ & 3 & 8 & $N v \cdot D$ & $-0.1 \pm 0.12$ & $-2.8 \pm 0.34$ & - \\
\hline $\mathrm{C}_{38}$ & 4 & IO & $N v . D$ & $0.0 \pm 0.26$ & $-2.8 \pm 0.20$ & $-I \cdot 2 \pm 0.33$ \\
\hline $\mathrm{C}_{38} 8$ & 4 & IO & $N v . R$ & $+0.1 \pm 0.23$ & $+0.3 \pm 0.23$ & $-0.4 \pm 0.31$ \\
\hline $\mathrm{C}_{38}$ & 4 & IO & $D$ ข. $R$ & $-0.1 \pm 0.28$ & $-3 \cdot 1 \pm 0.26$ & $-0.8 \pm 0.29$ \\
\hline
\end{tabular}

$N$, normal animals; $D$, deficient; $R$, recovery.

The ribonucleic acid content of the parathyroids was examined in series $\mathrm{C}_{3} 8$ only. Results were similar to those for leucine aminopeptidase: there was no difference between the parathyroids of normal and recovery animals, but the deficient animals had significantly more ribonucleic acid than both the normal $(P<0.01)$ and the recovery animals $(P<0.05)$.

The lactate dehydrogenase activity of the parathyroids appeared to be unaffected by the vitamin $\mathrm{D}$ status of the animals. 


\section{Bone}

All the results for bone are given in Table 3 .

The percentage of ash in bones from the deficient groups was always smaller than that in the normal groups, but the difference was very small after I and 2 weeks on the rachitogenic diet and only reached significance after $3(P<0.01)$ and $4(P<0.01)$ weeks. At 4 weeks the percentage of ash in bones from the recovery group lay between and was significantly different from that of the normal $(P<0.01)$ and the deficient $(P<0.01)$ groups.

Table 3. Mean values with their within-litters standard errors for percentage of ash in bones and osteoclast count of bones of rats given a rachitogenic diet with or without vitamin $D$

\begin{tabular}{|c|c|c|c|c|c|c|}
\hline \multirow[b]{2}{*}{$\begin{array}{l}\text { Series } \\
\text { no. }\end{array}$} & \multirow[b]{2}{*}{$\begin{array}{l}\text { Dosing } \\
\text { period }\end{array}$} & \multirow{2}{*}{$\begin{array}{l}\text { Weekly } \\
\text { dose of } \\
\text { vitamin D } \\
\text { (i.u.) }\end{array}$} & \multirow[b]{2}{*}{$\begin{array}{l}\text { No. of } \\
\text { rats }\end{array}$} & \multirow{2}{*}{$\begin{array}{c}\text { Bone ash } \\
\text { ( } g / \text { roog } \\
\text { dry } \\
\text { fat-frec } \\
\text { bone) }\end{array}$} & \multicolumn{2}{|c|}{ Osteoclasts* } \\
\hline & & & & & Field I & Field 2 \\
\hline$C_{35}$ & $\begin{array}{l}\mathbf{I} \\
\mathbf{I}\end{array}$ & $\begin{array}{l}0 \\
10\end{array}$ & $\begin{array}{l}\text { Io } \\
\text { 10 }\end{array}$ & $\left.\begin{array}{l}42 \cdot 3 \\
42 \cdot 6\end{array}\right\} \pm 0 \cdot 4 x$ & - & 一 \\
\hline $\mathrm{C}_{35}$ & $\begin{array}{l}2 \\
2\end{array}$ & $\begin{array}{r}0 \\
10\end{array}$ & $\begin{array}{l}8 \\
8\end{array}$ & $\left.\begin{array}{l}43 \cdot 9 \\
44 \cdot 6\end{array}\right\} \pm 0 \cdot 48$ & - & - \\
\hline $\mathrm{C}_{35}$ & $\begin{array}{l}3 \\
3\end{array}$ & $\begin{array}{l}0 \\
\text { I0 }\end{array}$ & $\begin{array}{l}8 \\
8\end{array}$ & $\left.\begin{array}{l}40.6 \\
44.8\end{array}\right\} \pm 0.52$ & - & - \\
\hline $\mathrm{C}_{3} 8$ & $\begin{array}{l}4 \\
4\left\{\begin{array}{l}\mathrm{fo} \\
\mathrm{fo}\end{array}\right.\end{array}$ & $\left.\begin{array}{cc} & 0 \\
10 \\
\text { eks } & 0 \\
\text { ek } & 10\end{array}\right\}$ & $\begin{array}{l}\text { Io } \\
\text { 10 } \\
\text { Io }\end{array}$ & $\left.\begin{array}{c}37 \cdot 7 \\
48 \cdot 8 \\
43 \cdot 6\end{array}\right\} \pm 0 \cdot 69$ & $\left.\begin{array}{r}4 \cdot 6 \\
12 \cdot 3 \\
6 \cdot 1\end{array}\right\} \pm 0.55$ & $\left.\begin{array}{r}5.2 \\
7 \cdot 6 \\
11 \cdot 8\end{array}\right\} \pm 0.69$ \\
\hline
\end{tabular}

* Osteoclasts were counted in two central fields of the ulna: field I, touching diaphyseal cdge of epiphyseal plate; field 2 , touching diaphyseal edge of field $\mathrm{I}$.

In series $\mathrm{C}_{35}$ alkaline phosphatase and in series $\mathrm{C}_{3} 8$ alkaline and acid phosphatases and succinate and lactate dehydrogenases were studied histochemically. After 2 or more weeks on the rachitogenic diet the difference in structure between the epiphyseal zone of the deficient and normal rats was characteristic; the epiphyseal plate of the deficient rats became greatly extended and changed in structure and the subepiphyseal zone became disorganized. Abnormal regions therefore existed in the deficient rats which did not exist in the normal, and comparison had either to be made between two dissimilar structures or the comparison regarded as invalid. We regarded the comparisons as invalid and therefore give no results. We did, however, make osteoclast counts on the sections prepared to show succinate dehydrogenase since the high activity of this enzyme in the osteoclasts differentiated them from all other bone cells.

Osteoclasts were counted in two central fields of the ulna, the first field touching the diaphyseal edge of the epiphyseal plate and the second field touching the diaphyseal edge of the first. The fields were circular and their area was $0.125 \mathrm{~mm}^{2}$. The fields in at least six sections were counted for each animal and the counts averaged. In the normal rat the mean osteoclast count was higher in field $I$ than in field 2 
Vol. 20

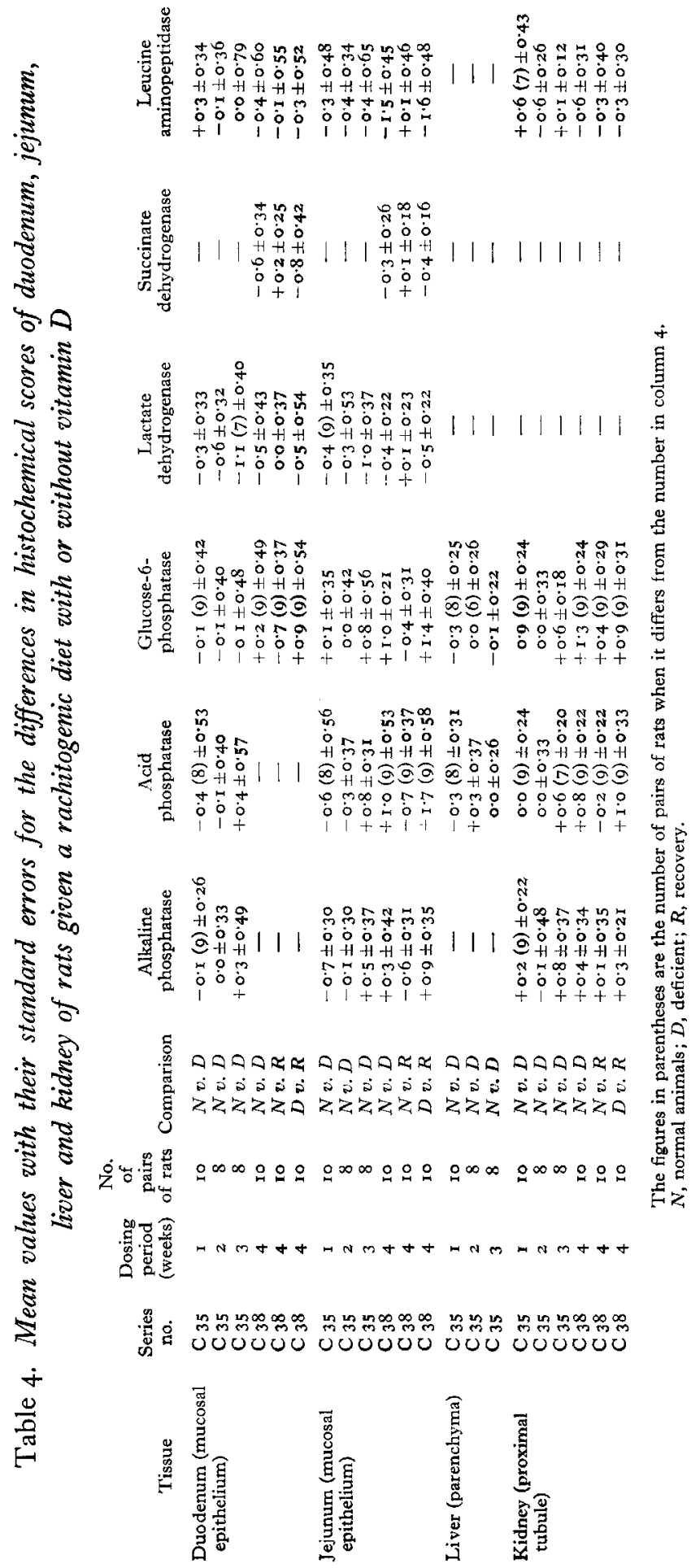


$(P<0.01)$, in the deficient there was no difference between the fields and in the recovery rat the count was higher in field 2 than in field I $(P<0.0 \mathrm{I})$.

\section{Histochemical changes in duodenum, jejumum, liver and kidney}

The means of the histochemical scores and their standard errors are given in Table 4 .

There were no changes in alkaline or acid phosphatases of the duodenal mucosal epithelium after I, 2 or 3 weeks of vitamin D deprivation. Since it had previously been shown that the activity of these enzymes was unaltered after longer periods of deprivation they were not studied in series $\mathrm{C}_{3} 8$. In the jejunum the score for alkaline phosphatase was significantly $(P<0.05)$ higher in the deficient rats after I week, but the difference diminished as the period of depletion was extended and at 3 and 4 weeks the mean score of the deficient group had fallen below that of the normal group. After dosing with vitamin $\mathrm{D}$, the recovery group had more alkaline phosphatase activity than the normal group and significantly $(P<0.05)$ more than the deficient group. The pattern of change in the jejunal acid phosphatase was identical with that of the alkaline phosphatase; the activity of the normal was significantly higher than that of the deficient at 3 weeks $(P<0.05)$, the recovery was higher than the normal and significantly higher $(P<0.05)$ than the deficient. There were no changes in the glucose-6-phosphatase activity of the duodenum and none in the jejunum after I, 2 or 3 weeks vitamin $\mathrm{D}$ deprivation. In the jejunum, after 4 weeks deprivation the activity of the deficient was less than that of both the normal $(P<0.01)$ and the recovery $(P<0.01)$.

Lactate dehydrogenase activity was significantly higher in the duodenal $(P<0.05)$ and jejunal $(P<0.05)$ mucosal epithelium of the deficient group after 3 weeks deprivation. In the jejunum, after 4 weeks although the dehydrogenase activity of the deficient group was now not significantly higher than that of the normal it was higher $(P<0.05)$ than that of the recovery group. Succinate dehydrogenase activity was investigated only in series $\mathrm{C}_{3} 8$ and showed a result similar to that for lactate dehydrogenase, i.e. the activity of the deficient was greater than that of the recovery $(P<0.05)$.

The only change in leucine aminopeptidase activity of the epithelium of the duodenum or jejunum was that the activity of the jejunum of the deficient group was significantly greater than that of both the normal $(P<0.01)$ and the recovery $(P<0.01)$ after 4 weeks deprivation.

In the liver only acid phosphatase and glucose-6-phosphatase were studied and, since these showed no changes in series $\mathrm{C}_{35}$, they were not studied in series $\mathrm{C}_{3} 8$.

In the kidney there were no changes in alkaline phosphatase activity in either series. The acid phosphatase activity was lower in the deficient groups after $3(P<0.05)$ and $4(P<0.01)$ weeks deprivation and was also significantly lower than that of the recovery group $(P<0.05)$. Changes in glucose-6-phosphatase activity were similar; activity was lower in the deficient than in the normal after $3(P<0.01)$ and 4 $(P<0.01)$ weeks deprivation and lower than in the recovery group $(P<0.05)$. Leucine aminopeptidase activity was higher in the deficient group after 2 weeks deprivation $(P<0.05)$. 
DISCUSSION

The earliest sustained change observed in the vitamin D-deficient rat was the increased leucine aminopeptidase activity of the parathyroid, which first appeared after 2 weeks deprivation. The increase in parathyroid activity in vitamin D deprivation, indicated by this rise in leucine aminopeptidase, was confirmed by the observation of a rise in the ribonucleic acid content of the glands of the deficient rat and the return of both leucine aminopeptidase and ribonucleic acid to the level in the normal rat when vitamin $\mathrm{D}$ was administered to previously deprived animals.

The low plasma calcium which is found in the vitamin D-deficient rat (Rasmussen, DeLuca, Arnaud, Hawker \& von Stedingk, 1963 ; Toverud, $1964 a$ ) is a stimulus to increased parathyroid activity (Patt \& Luckardt, 1942). Toverud (1964b) has shown that the gut, the kidney and the bones still respond to parathyroid hormone in the vitamin D-deficient rat. It is possible therefore that the transitory rises in enzyme activity in the gut and the kidney of the vitamin $\mathrm{D}$-deficient rat represent a response to the elevated level of parathyroid hormone whilst the sustained falls in activity, particularly of the jejunal and kidney phosphatases reflect the inability of the parathyroid to bring about full compensation to prolonged vitamin $\mathrm{D}$ deficiency. The tendency of the phosphatases of the jejunum of the recovery group to rise above the normal level could represent the combined effect of the response to vitamin $D$ and the delayed response to the fall in parathyroid hormone. Kodicek, Cruickshank, DeLuca \& Raisz (1964) have shown that the response of the gut to parathyroidectomy is delayed; the response to falling parathyroid secretion must therefore be slow to show its full effect.

The rise in parathyroid activity in the vitamin D-deficient rat preceded by I week the fall in ash content of bone. The bones were therefore relatively slowly affected by lack of vitamin D. Similarly, when vitamin D was administered to previously deprived rats, the parathyroid recovered fully in I week, whereas the bones were only partially recovered. On histological examination of the bones, it was seen that the epiphyseal plate of the recovery rat differed little from that of the normal, but that the zone, which in the normal lies just below the epiphyseal plate and where bone deposition is most active, was in the recovery rat further down the shaft. A high osteoclast count was associated with this zone. The low osteoclast count in the vitamin D-deficient rat was surprising in view of the observation of Talmage \& Toft (196r) that the number of osteoclasts in the subepiphyseal zone rises in response to raised parathyroid activity. Whether this rise is dependent upon the presence of vitamin D merits further investigation. 


\section{REFERENCES}

Balogh, K. Jr. (r962). F. Histochem. Cytochem. ro, 232.

Cheesman, E. M., Copping, A. M. \& Prebble, P. M. (1964). Br. F. Nutr. 18, 447.

Hume, E. M., Pickersgill, M. \& Gaffikin, M. M. (1932). Biochem. F. 26, 488.

Kodicek, E., Cruickshank, E. M., DeLuca, H. F. \& Raisz, L. G. (1964). In Bone and Tooth, p. $3^{6} 3$. [H. J. J. Blackwood, editor.] Oxford: Pergamon Press.

Patt, H. M. \& Luckhardt, A. B. (1942). Endocrinology 31, 384.

Pearse, A. G. E. ( 1960 ). Histochemistry, and ed. London: J. and A. Churchill.

Rasmussen, H., DeLuca, H., Arnaud, C., Hawker, C. \& von Stedingk, M. (1963). F. clin. Invest. 42, I940.

Talmage, R. V. \& Toft, R. J. (r96r). In The Parathyroids, p. 224. [R. O. Greep and R. V. Talmage, editors.] Springfield: C. C. Thomas.

Toverud, S. U. (1964a). Acta physiol. scand. 62, 391.

Toverud, S. U. (1964b). Acta physiol. scand. 62, Suppl. 234. 